\title{
Protein pump inhibitors esomeprazole and pantoprazole increase the chemosensitivity of Cml cells against imatinib
}

\section{Protein pompa inhibitörleri esomeprazol ve pantoprazol KML hücrelerinin imatinibe karşı kemosensitivitesini artırmaktadır}

\author{
Merve Ergüil $1^{1 *}$, Mustafa Ergüil ${ }^{2}$
}

Department of Pharmacology, Faculty of Pharmacy, Sivas Cumhurivet University, Sivas, Turke

${ }^{2}$ Department of Biochemistry, Faculty of Pharmacy, Sivas Cumhuriyet University, Sivas, Turkey

Corresponding author: Merve Ergül, PhD., Department of Pharmacology, Faculty of Pharmacy, Cumhuriyet University, Sivas, Turkey

E-mail: mergulmerve@gmail.com,minanir@cumhuriyet.edu.tr

Received/Accepted: December 19, 2018 / December 25, 2018

Conflict of interest: There is not a conflict of interest.

\begin{abstract}
SUMMARY
Objective: Proton pump inhibitors (PPIs) largely used drug to treat gastroesophageal disease such as gastric ulcers. Moreover, in recent years, several studies suggest that PPIs have important anti-cancer effect in monotherapy and or combination with chemotherapy.

The aim of this study was to investigate whether esomeprazole and pantoprazole exhibit anti-cancer effect alone or could enhance chemosensitivity of CML cell line K562 to imatinib.

Method: Human chronic myeloid leukemia (CML) cells were cultured and treated with different concentrations of esomeprazole, pantoprazole, and imatinib alone. Also these cells exposed to imatinib + esomeprazole and imatinib + pantoprazole combinations, respectively and incubated $24 \mathrm{~h}$. The antiproliferative activities of the (PPIs) alone or in combination of imatinib was evaluated using the XTT colorimetric assay.

Results: According to experimental data, neither PPIs showed any cytotoxicity on the K562 cell line at all concentrations except at 500 and $1000 \mu \mathrm{M}$. However, when combined with imatinib separately, they were found to have significant anti-cancer effects on K562 cells when compared to cell lines treated with imatinib alone $(\mathrm{p}<0.05)$.

Conclusions: Taken together, the inhibition of V-ATPase via esomeprazole and pantoprazole might enhance the chemosensitivity of imatinib in CML cells. However, further studies are needed to be able to utilize PPIs in CML.
\end{abstract}

Keywords: Chronic myeloid leukemia, esomeprazole, pantoprazole, V-ATPase

\section{ÖZET}

Amaç: Proton pompa inhibitörleri (PPI) gastrik ülserler gibi gastroözofageal hastalıklarda kullanılan ilaçlardır. Bununla birlikte son yıllarda PPI'lerin tek başlarına veya kemoterapötik ajanlarla kombine halde kullanımlarının önemli antikanser etkiye sahip olduğu bildirilmektedir.

$\mathrm{Bu}$ çalışmanın amacı esomeprazol ve pantaprazol'ün tek başlarına antikanser etkili olup olmadıklarının veya KML hücrelerinin imatinibe karşı hassasiyetini artırıp artırmayacağının araştırılmasıdır.

Yöntem: İnsan kronik miyeloid lösemi (KML) hücreleri kültüre edildi ve hücrelere farklı konsantrasyonlarda esomeprazol, pantoprazol ve imatinib tek başlarına uygulandı. Ayrıca hücreler üzerine imatinib + esomeprazol ve imatinib + pantoprazol kombinasyonları ayrı ayrı uygulanarak 24 saat inkübe edildi. PPİ'lerin tek başına ve imatinib ile kombinasyonlarına ait antiproliferatif aktiviteleri XTT testi ile değerlendirildi.

Bulgular: Deneysel verilere göre her iki PPİ de 500 ve $1000 \mu \mathrm{M}$ hariç uygulanan bütün dozlarda K562 hücreleri üzerinde herhangi bir sitotoksisite göstermemiştir. Bununla birlikte imatinib ile ayrı ayrı kombine edildiklerinde, imatinibin tek başına uygulandığı gruba göre K562 hücreleri üzerinde önemli antikanser etkilerinin olduğu belirlenmiştir $(\mathrm{p}<0.05)$. 
Sonuç: Sonuçlar birlikte değerlendirildiğinde, esomeprazol ve pantaprazol aracılı V-ATPaz inhibisyonunun KML hücrelerini imatinibe daha duyarlı hale getirebileceği düşünülmektedir. Bununla birlikte, PPI’lerin KML de kullanılabilmesi için ileri çalışmalara ihtiyaç vardır.

Anahtar sözcükler: Kronik miyeloid lösemi, esomeprazol, pantoprazol, V-ATPaz

\section{INTRODUCTION}

Today, cancer is a major health issue in the world and is the second-leading cause of death in the US after cardiovascular diseases ${ }^{1}$. Chronic myeloid leukemia (CML) is a hematopoietic disorder that is characterized by the presence of $\mathrm{BCR}-\mathrm{ABL}$ fusion oncogene which encodes the BCR-ABL fusion protein and this protein possess tyrosine kinase activity, leading to leukemogenesis ${ }^{2,3}$. It is recognized that targeting of $\mathrm{BCR}-\mathrm{ABL}$ with strong inhibitors such as imatinib, nilotinib and dasatinib is an effective strategy for CML therapy and most patients well respond to the treatment. However, depending on BCR-ABL kinase mutations the resistance of tumours to anticancer drug imatinib, which causes poor prognosis, may develop some patients especially advanced cases during treatment ${ }^{4}$. Therefore, novel therapeutic strategies for CML treatment are urgently needed to overcome chemoresistance.

One of the new strategies is to increase the effectiveness of chemotherapeutic drugs by inhibiting vacuolar adenosine triphosphatases (VATPases), which regulates the lysosomal $\mathrm{pH}$, in cancer cells. It is known that tumor cells show an alkaline intracellular $\mathrm{pH}$ and an acidic extracellular $\mathrm{pH}$. Unfortunately, this low $\mathrm{pH}$ in cancer cells is closely related to the development of drug resistance ${ }^{5,6}$. Increased $\mathrm{H}+$ ions outside of cancer cells may cause protonation and neutralization of chemotherapeutic drugs, which reduces the uptake of drugs into the cell. This acidic microenvironment also causes high levels of proton pump expression of cancer cells? Existing data suggest that proton pumps, especially V-ATPases are involved in metastasis, invasion and multidrug-resistance in various cancer types including prostate cancer, pancreatic cancer, breast cancer, hepatocellular carcinoma, and oral squamous cell carcinoma ${ }^{8}$. Several reports have also been demonstrated that inhibition of V-ATPases by using various PPIs affect cancer cells homeostasis and as a result inhibit cancer cell proliferation, enhance cytotoxicity of chemotherapeutics and induce autophagy $^{9-11}$. Therefore, combined use of PPIs with chemotherapeutic agents has been gaining increasing attention in the cancer treatment.

Based on the above information, in the present study we aimed to investigate whether esomeprazole and pantoprazole could enhance chemosensitivity of CML cell K562 to imatinib. To the best of our knowledge, this is the first study to investigated the effects of esomeprazole and pantoprazole alone and combine with imatinib on K562 cell lines.

\section{MATERIAL AND METHODS}

\section{In-vitro cytotoxicity assay}

\section{Cell culture}

The cytotoxicity of the esomeprazole/pantoprazole alone and combine with imatinib was tested against human chronic myelogenous leukemia, K562 cell line (Manassas, VA, USA).The cells were cultured in RPMI-1640 (Gibco Thermo Fisher Scientific) containing 10\% FBS, $1 \%$ L-glutamine, $100 \mathrm{IU} / \mathrm{mL}$ penicillin and $10 \mathrm{mg} / \mathrm{mL}$ streptomycin (Gibco Thermo Fisher Scientific) in $25 \mathrm{~cm}^{2}$ polystyrene flasks and maintained in a humidified atmosphere with 5\% $\mathrm{CO}_{2}$ at $37{ }^{\circ} \mathrm{C}$. Growth and morphology were monitored and the cells were passaged when they had reached almost $85 \%$ confluence.

\section{Cell viability assay}

Cell viability was evaluated using the XTT (2,3bis-(2-methoxy-4-nitro-5-sulfophenyl)-2H-

tetrazolium-5-carboxanilide) assay (Roche Diagnostic, Germany) against the K562 cells. PPIs and imatinib were dissolved in RPMI-1640 and stock solutions were prepared. Then these stocks were diluted in RPMI-1640 and various concentrations were prepared prior to treatment. The K562 cells were seeded in 96-well plates at a density of $1 \times 10^{4}$ cells per well in $100 \mu \mathrm{l}$ colorless RPMI-1640 medium and the cells were treated with the PPIs alone (ranging from 1 to $1000 \mu \mathrm{M})$ or combined with imatinib at $1 \mu \mathrm{M}$ (this concentration is the IC50 value determined for imatinib in this study) concentrations and incubated for $24 \mathrm{~h}$. At the end of the incubation 
period, for cytotoxicity, $50 \mu \mathrm{L}$ XTT labeling mixture were added to each well and then the plates were incubated at $37^{\circ} \mathrm{C}$ for four h. Finally, the absorbance of XTT-formazan was measured using a microplate (ELISA) reader at $450 \mathrm{~nm}$ against the control. All experiments were performed in three independent experiments and the cell viability was expressed in \% related to control (100\% of viability).

\section{Statistical Analyses}

Statistical analysis was carried out using GraphPad Prism 7 version and all data are expressed as mean \pm SEM. Groups were compared statistically using general linear models of analysis of variance (ANOVA) followed by Tukey test. $\mathrm{P}$ values less than or equal to 0.05 were considered to be statistically significant.

\section{RESULTS AND DISCUSSION}

\section{Inhibition of Cell Proliferation}

In the present study, XTT cell proliferation assay was performed to assess antiproliferative effects of the PPIs alone and combined with imatinib on K562 cells for $24 \mathrm{~h}$. At first, to determine the cytotoxicity of PPIs alone, exponentially growing cells were treated with increasing concentrations of esomeprazole and pantoprazole and incubated for $24 \mathrm{~h}$. Then, to determine the $\mathrm{IC}_{50}$ value of imatinib on K562 cells, imatinib was administrated on K562 cells at various concentrations and incubated for $24 \mathrm{~h}$ (Figure 1). This $\mathrm{IC}_{50}$ value of imatinib was also used in combination with PPIs. According to experimental results, neither esomeprazole and pantoprazole exhibited any cytotoxicity on the K562 cell line except at 500 and $1000 \mu \mathrm{M}$ (Figure 2). Moreover, we were interested if esomeprazole and pantoprazole might affect the sensitivity of K562 cells towards frequently used antineoplastic drug imatinib. We hence treated K562 cells with esomeprazole + imatinib or pantoprazole + imatinib combinations respectively at the $\mathrm{IC}_{50}$ concentrations. As presented in Figure $\mathbf{3}$, an important loss of viability was observed in both combinations especially at 50, 100, 250, 500 and $1000 \mu \mathrm{M}$ concentrations at $24 \mathrm{~h}$. This results suggested that when compared with imatinib treatment alone, esomeprazole and pantoprazole pretreatment significantly enhanced the cytotoxicity of imatinib in K562 cells.

\section{Imatinib}

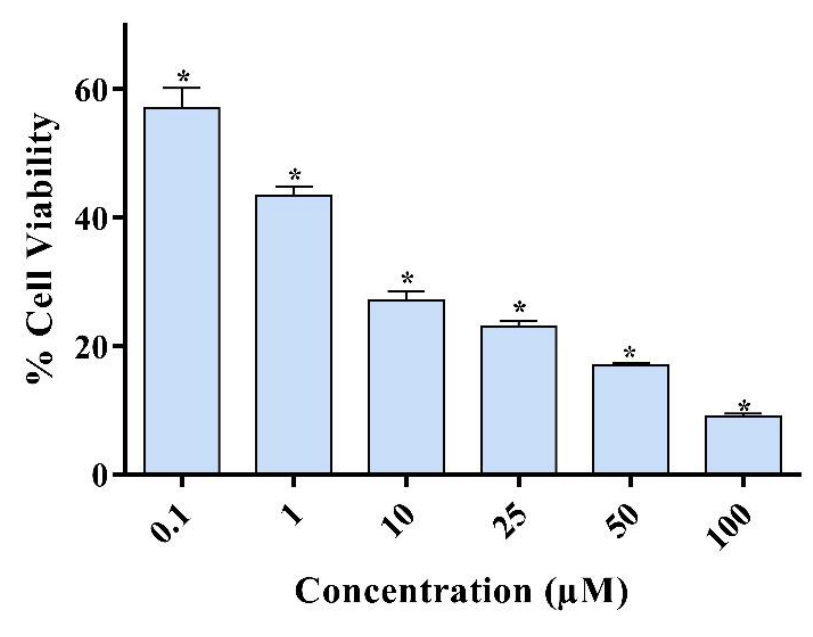

Figure 1. Antiproliferative activity of imatinib on K562 cells. Data are expressed as mean \pm SEM in three experiments and the differences are identified as $*$ from control $\mathrm{p}<0.05$. 
Proton Pump Inhibitors

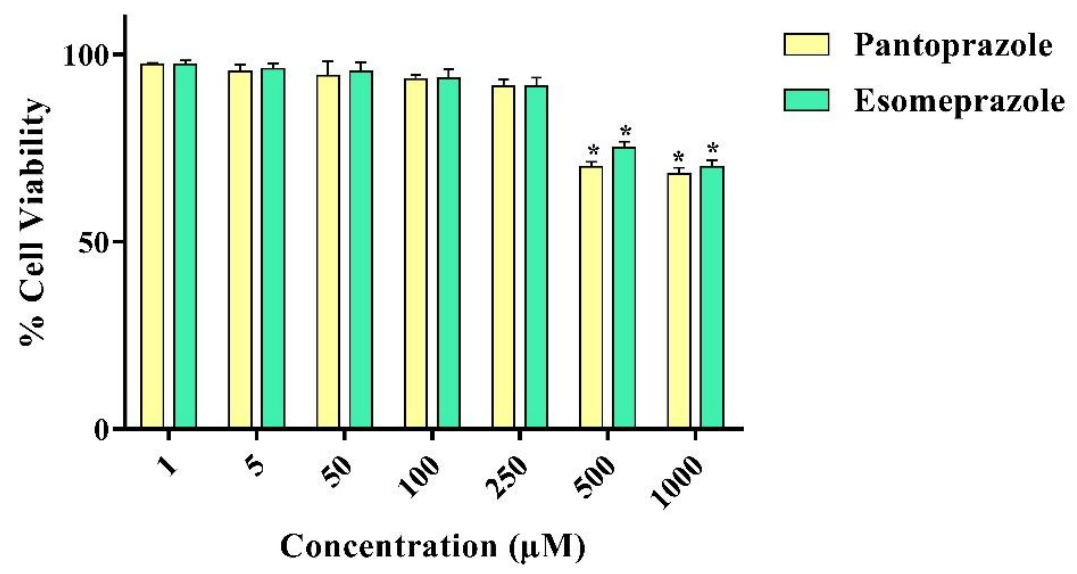

Figure 2. The effects of pantoprazole and esomeprazole on viability of K562 cells. The cells were treated with different concentrations of pantoprazole and esomeprazole ranged between 1 and $1000 \mu \mathrm{M}$ and the cytotoxicity was determined by XTT assay. The differences are *p $<0.05$ compared with control cells.

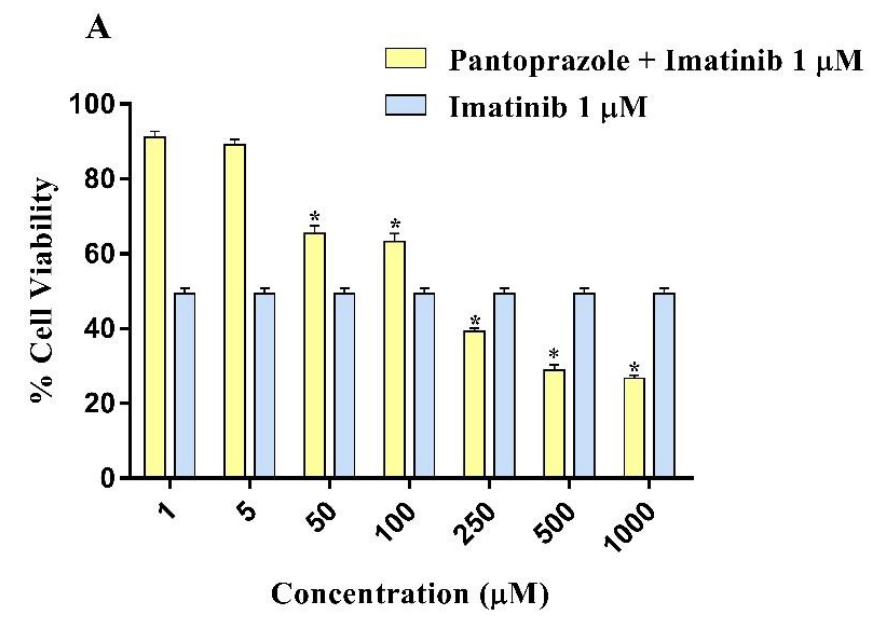

B

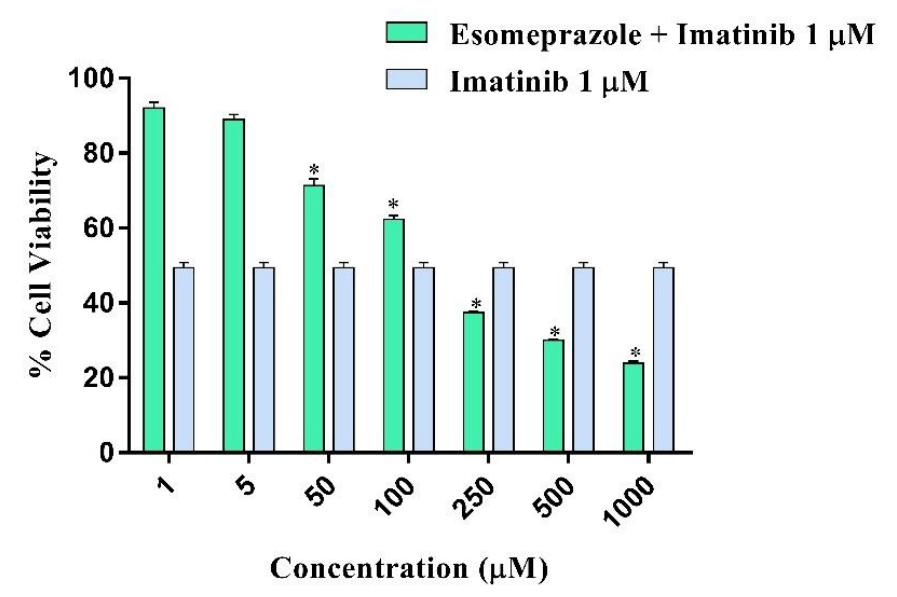

Figure 3. The effects of different concentrations of pantoprazole/esomeprazole and imatinib $(1 \mu \mathrm{M})$ combination on viability of K562 cells. The differences are $* p<0.05$ compared with pantoprazole or esomeprazole alone. 
In the literature, anti-cancer effects of various PPIs are currently being evaluated for treatment of various tumors such as pancreatic cancer, melanoma, and colon cancers ${ }^{5,9,12}$. Furthermore, to the best of our knowledge, no studies have been conducted on the investigation of the effects of PPIs on K562 cells. In a recent study, it has been reported that esomeprazole enhanced the cytotoxicity of paclitaxel in various cervical cancer cells HeLa and INT407 ${ }^{10}$. In a different study, Lindner et al. reported that the esomeprazole significantly inhibited tumor cell survival and increased the cytotoxic effect of cisplatin and 5-FU in esophageal cancer cells ${ }^{8}$. A similar in vitro study demonstrated that the PPI pantoprazole enhances the chemosensitivity of CRC, HT29 and RKO cells to fluorouracil (5$\mathrm{FU})^{7}$. Similar results were reported for the esomeprazole and pantoprazole in our study.

\section{CONCLUSION}

In conclusion, inhibition of the V-ATPase by using PPIs (esomeprazole and pantoprazole) enhanced the chemosensitivity of K562 cells to imatinib. Our findings suggest that esomeprazole and pantoprazole may be useful as a chemosensitizer in the treatment of patients with chronic myeloid leukemia. However, the large prospective clinical studies are needed.

\section{REFERENCES}

1. Ergül M, Ergül M, Tutar Y. Important AntiCancer Applications of Protein Based Nanoparticles. Current Proteomics 2013;10:334340.

2. Inoue $\mathrm{A}$, Kobayashi $\mathrm{CI}$, Shinohara $\mathrm{H}$, et al. Chronic myeloid leukemia stem cells and molecular target therapies for overcoming resistance and disease persistence. Int $\mathrm{J}$ Hematol 2018;108(4):365-370.

3. Dalgıç CT, Kaymaz BT, Özkan MC, et al. Investigating the Role of JAK/STAT Pathway on Dasatinib-Induced Apoptosis for CML Cell Model K562. Clin Lymphoma Myeloma Leuk 2015;15.

4. Li X, Pang J, Xue W, et al. Inducible SHP-2 activation confers resistance to imatinib in drugtolerant chronic myeloid leukemia cells. Toxicol Appl Pharmacol 2018;360:249-256.

5. Udelnow A, Kreyes A, Ellinger $S$, et al. Omeprazole inhibits proliferation and modulates autophagy in pancreatic cancer cells. PLoS One 2011;6(5):e20143.
6. Lu ZN, Tian B, Guo XL. Repositioning of proton pump inhibitors in cancer therapy. Cancer Chemother Pharmacol 2017;80(5):925-937.

7. Wang X, Liu C, Wang J, et al. Proton pump inhibitors increase the chemosensitivity of patients with advanced colorectal cancer. Oncotarget 2017;8(35):58801-58808.

8. Lindner K, Borchardt C, Schöpp $M$, et al. Proton pump inhibitors (PPIs) impact on tumour cell survival, metastatic potential and chemotherapy resistance, and affect expression of resistance-relevant miRNAs in esophageal cancer. J ExpClin Cancer Res 2014;33:73.

9. Marino ML, Fais S, Djavaheri-Mergny M, et al. Proton pump inhibition induces autophagy as a survival mechanism following oxidative stress in human melanoma cells. Cell Death Dis 2010;1:e87.

10. Song T, Jeon HK, Hong JE, et al. Proton Pump Inhibition Enhances the Cytotoxicity of Paclitaxel in Cervical Cancer. Cancer Res Treat 2017;49(3):595-606.

11. Hou Y, Hu Q, Huang J, Xiong H. Omeprazole Inhibits Cell Proliferation and Induces G0/G1 Cell Cycle Arrest through Up-regulating miR-203a-3p Expression in Barrett's Esophagus Cells. Front Pharmacol 2018;8:968.

12. Patlolla JM, Zhang $Y$, Li Q, et al. Anticarcinogenic properties of omeprazole against human colon cancer cells and azoxymethaneinduced colonic aberrant crypt foci formation in rats. Int J Oncol 2012;40(1):170-5. 